U. S. DEPARTMENT OF AGRICULTURE, BUREAU OF CHEMISTRY-BULLETIN No. 155.

H. W. WILEY, Chief of Bureau.

\title{
LARGE SCALE EXPERIMENTS ON THE PROCESSING OF JAPANESE PERSIMMONS;
}

WITH NOTES ON

THE PREPARATION OF DRIED PERSIMMONS.

H. C. GORE, Assistant Chemist, Division of Foods.

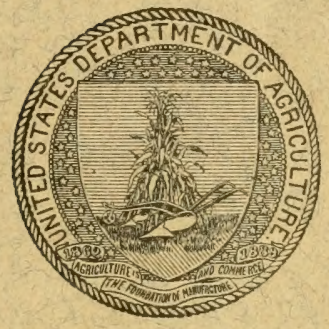




\section{ORGANIZATION OF BUREAU OF CHEMISTRY.}

R. E. Doolittle, Acting Chief of Bureau.

F. L. Dunlap, Associate Chemist.

W. D. Brgelow, Assistant Chief of Bureau.

F. B. Linton, Chief Clerk,

J. G. Shibley, Supervisory Clerk, Interstate and Import Records.

A. L. Pierce, Editor.

A. E. DrAPER, Librarian.

Division of Foods, W. D. Bigelow, Chief.

Food Inspection Laboratory, L. M. Tolman, Chief.

Food Technology Laboratory, E. M. CHACE, Chief, and Assistant Chief of Division.

Oil, Fat, and Wax Laboratory, H. S. BaIley, Chief.

Division of Drugs, L. F. KeBLer, Chief.

Drug Inspection Laboratory, G. W. Hoover, Chief.

Synthetic Products Laboratory, W. O. Emerx, Chief.

Essential Oils Laboratory, E. K. NeLson, Chief.

Pharmacological Laboratory, Wibliam Salant, Chief.

Chief Food and Drug Inspector, W. G. CaMpBell.

Miscellaneous Division, J. K. HAYwood, Chief.

Water Laboratory, W. W. SkINNER, Chief.

Cattle-Food and Grain Laboratory, G. L. Binwel, Acting.

Insecticide and Fungicide Laboratory, C. O. McDonnelt, Chief.

Trade Wastes Laboratory, under Chief of Division.

Contracts Laboratory, P. H. WALKer, Chief.

Dairy Laboratory, G. E. PAtrick, Chief.

Food Research Laboratory, M. E. Pennington, Chief.

Leather and Paper Laboratory, F. P. Vегтch, Chief.

Microchemical Laboratory, B. J. Howard, Chief.

Physical Chemistry Laboratory, C. S. Hudson, Chief.

Sugar Laboratory, A. H. Bryan, Chief.

Sections:

Animal Physiological Chemistry, F. C. Weỉer, in Charge.

Bacteriological Chemistry, G. W. Stines, in Charge.

Enological Chemistry, W. B. Atwoon, in Charge.

Nitrogen, T. C. Trescot, in Charge.

Plant Physiological Chemistry, J. A. LeClero, Chief.

Food Technologist, A. W. BitTing.

Food and Drug Inspection Laboratories:

Boston, B. H. SмIтн, Chief.

Buffalo, W. L. Dusors, Chief.

Chicago, A. L. Wrnton, Chief.

Cincinnati, B. R. HART, Chief.

Denver, R. S. HILtner, Chief.

Detroit, H. L. Schurz, Chief.

Galveston, G. M. Bartlett, Acting.

Honolulu, Hawaii, A. W. Hanson, Acting.

Kansas City, Mo., F. W. Likpsner, Chief.

Nashville, R. W. Balcom, Chief.

New Orleans, W. J. McGee, Chief.

New York, A. W. OGDEN, Acting.

Omaha, S. H. Ross, Chief.

Philadelphia, C. S. Brinton, Chief.

Pittsburgh, M. O. Albrech,-Chief.

Portland, Oreg., A. L. Knisely, Chief.

St. Louis, D. B. Bisbee, Chief.

St. Paul, A. S. Mrtchelt, Chief.

San Francisco, R. A. Gould, Chief.

San Juan, P. R., A. E. TAylor, Acting.

Savannah, W. C, Bunnet, Chief.

Seattle, H. M. Looms, Chief. 
U. S. DEPARTMENT OF AGRICULTURE, BUREAU OF CHEMISTRY - BULLETIN No. 155.

H. W. WILEY, Chief of Bureau.

\title{
LARGE SCALE EXPERIMENTS ON THE PROCESSING OF JAPANESE PERSIMMONS;
}

WITH NOTES ON

THE PREPARATION OF DRIED PERSIMMONS.

\author{
BY \\ H. C. GORE, \\ Assistant Chemist, Division of Foods.
}

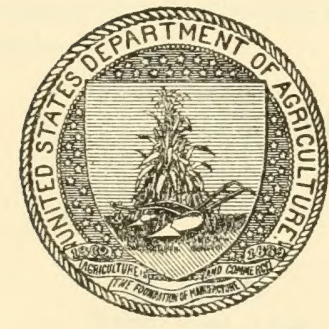

WASHINGTON:

GOVERNMENT PRINTING OFFIOE.

1912. 


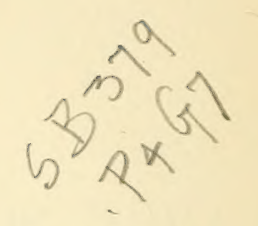

\section{LETTER OF TRANSMITTAL.}

\section{U. S. Department of Agriculture,} Bureau of Chemistry, Washington, D. C., March 14, 1912.

SIR: I have the honor to submit for your approval an account of certain experiments which have been conducted during the past year by H. C. Gore, of this bureau, on the processing of Japanese persimmons on a large scale and on the preparation of the dried fruit. Mr. A. V. Stubenrauch, of the Bureau of Plant Industry, has cooperated with Mr. Gore throughout the course of the work, giving advice as to the general scope and conduct of the experiments. From the data herein recorded explicit directions for processing persimmons on a large scale may be formulated and an idea obtained of the probable place that processing may hold in the persimmon industry. The preparation of dried persimmons on a laboratory scale indicates that a product of excellent quality may be obtained by the use of simple methods.

I recommend that this manuscript be printed as Bulletin 155 of the Bureau of Chemistry.

Respectfully,

Hon. JAMES WILsON,
H. W. WILEY, Chief of Bureau.

Secretary of Agriculture. 


\section{CONTENTS.}

Page.

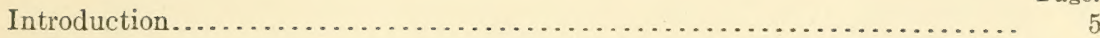

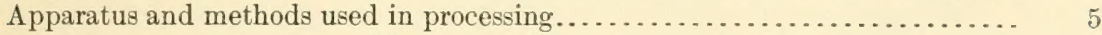

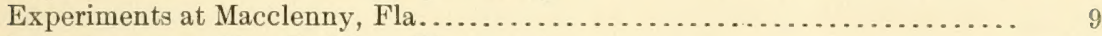

Experiments at Glen St. Mary, Fla......................... 12

Experiments at Washington, D. C . . . . . . . . . . . . . . . . . 12

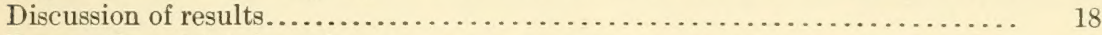

Preparation of dried persimmons. . . . . . . . . . . . . . . . . . . 19

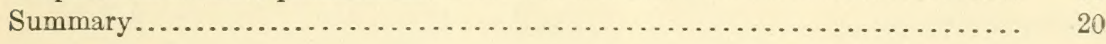

\section{L L US T R A T I O N S.}

FIG. 1. Apparatus used in processing Japanese persimmons................

2. Rate of softening of processed and unprocessed Tane-nashi persimmons

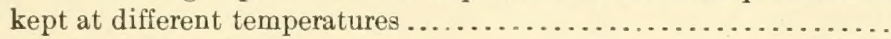

3. Rate of softening of processed and unprocessed Zengi persimmons kept at different temperatures. 



\section{LARGE SCALE EXPERIMENTS ON THE PROCESSING OF JAPANESE PERSIMMONS; WITH NOTES ON THE PREPARA- TION OF DRIED PERSIMMONS.}

\section{INTRODUCTION.}

During the seasons of 1907 to 1910 , inclusive, experiments on Japanese persimmons were carried on in cooperation with Mr. Taylor and Mr. Fairchild, of the Bureau of Plant Industry. ${ }^{1}$ It was found that upon keeping the fruit for several days in an inert gas such as carbon dioxid it becomes nonastringent while remaining firm. During the season of 1911 experiments on processing in carbon dioxid were extended to a semicommercial scale in order to determine the value of the method when applied to the commonly grown varieties of Japanese persimmons.

In the experiments described herein, except when otherwise noted, the persimmons to be processed were placed in large containers of galvanized iron, which were then tightly closed. The air was then displaced by carbon dioxid. When the fruits had become nonastringent they were removed and kept under observation in comparison with check lots consisting of unprocessed fruits of the same picking, to determine the effect of the treatment on their keeping and shipping qualities. Each variety so treated in Florida was subjected to a shipping test, while the persimmons processed by keeping in carbon dioxid at Washington were used in studies on keeping at different temperatures.

\section{APPARATUS AND METHODS USED IN PROCESSING.}

The apparatus used in processing is shown in figure 1. It consisted of tanks of galvanized iron (A), in which the fruit was processed on a large scale, glass desiccators (B), in which a few persimmons could be treated at a time, and liquefied carbon dioxid in steel cylinders $(\mathrm{C})$. Each of the galvanized iron boxes was 25 inches square and 24 inches high. It was large enough to hold four of the six-basket carriers commonly used in shipping persimmons. The upper edge and cover were so constructed that the box could be closed air-tight by means of clamps. This construction, shown in detail at (D), was designed by Mr. S. J. Dennis, of the Bureau of Plant 
Industry, and proved entirely satisfactory. The cost per box, with accessories, was as follows:

For box and cover.

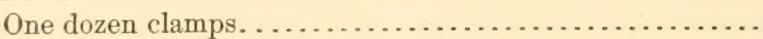

Three brass stopcocks, at 27 cents each..................

One and one-fourth pounds of white rubber tubing, at 79

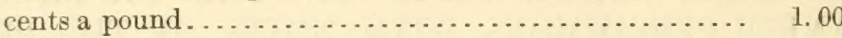

Total................................ 22.81

It is recognized, however, that some changes would be desirable if tanks for processing persimmons were to be made in quantity. In such a design the rims of the tanks and covers should be made of cast iron hinged together and fitted with eyebolts and slots. The adjacent surfaces should be planed and a solid rubber gasket used. The design shown in figure 1 does not require special castings.

In processing persimmons these tanks are filled with the fruit, which may be packed, if desired, in the standard six-basket carriers, and may or may not be wrapped. The cover is clamped in position, and the box tested for tightness by use of the water gauge $(\mathrm{E})$. It should be entirely free from leaks on the bottom or sides, and so tight that the rate of equalization of small differences in pressure, indicated by the gauge, is slow. Carbon dioxid is then passed in through the lower stopcock, while the displaced air flows out at the upper stopcock on the opposite side. The water gauge is useful here in guarding against too high pressures, which might easily cause permanent distortion in shape, or bursting. The flow of carbon dioxid is continued until the stream of displaced air tastes strongly of carbon dioxid. After such a taste is noted, the flow is continued for a few minutes longer; the stopcocks are then closed and the box left undisturbed for the time required in processing.

The necessity of opening the tanks to ascertain the progress of the processing should be avoided by placing a few persimmons in process in smaller containers. The most convenient apparatus for this purpose is the tubulated glass desiccator of the pattern shown in (B), which may be obtained from dealers in scientific apparatus. It should be kept at the same temperature as that of the tanks, on account of the influence of temperature on the rate of processing. (See p. 14.) As shown in (B), it is fitted with a rubber stopper carrying necessary delivery tubes. These may be of glass, or preferably of copper or other metal. The stopper should be well lubricated before forcing it into place, so that it will fit air-tight, and then be tied in position. The ground-glass surfaces must be plane. They are coated with vaseline. In displacing the air the carbon dioxid is passed in through the delivery tube, which reaches to the bottom of the desiccator. It is well to fasten the cover in place with cord or small clamps, because increases in pressure in the desiccator occasioned by the formation of carbon dioxid in the fruit may cause it to pop off 
suddenly. The fruits in the desiccator are examined from time to time to determine when processing is completed, taking care to close at once after opening and to renew the supply of carbon dioxid quickly.

Carbon dioxid may be purchased from dealers in soda-water supplies in liquefied form in steel cylinders holding 10 or 20 pounds at about 10 cents per pound. This is equal to a cost of about 1.1 cents

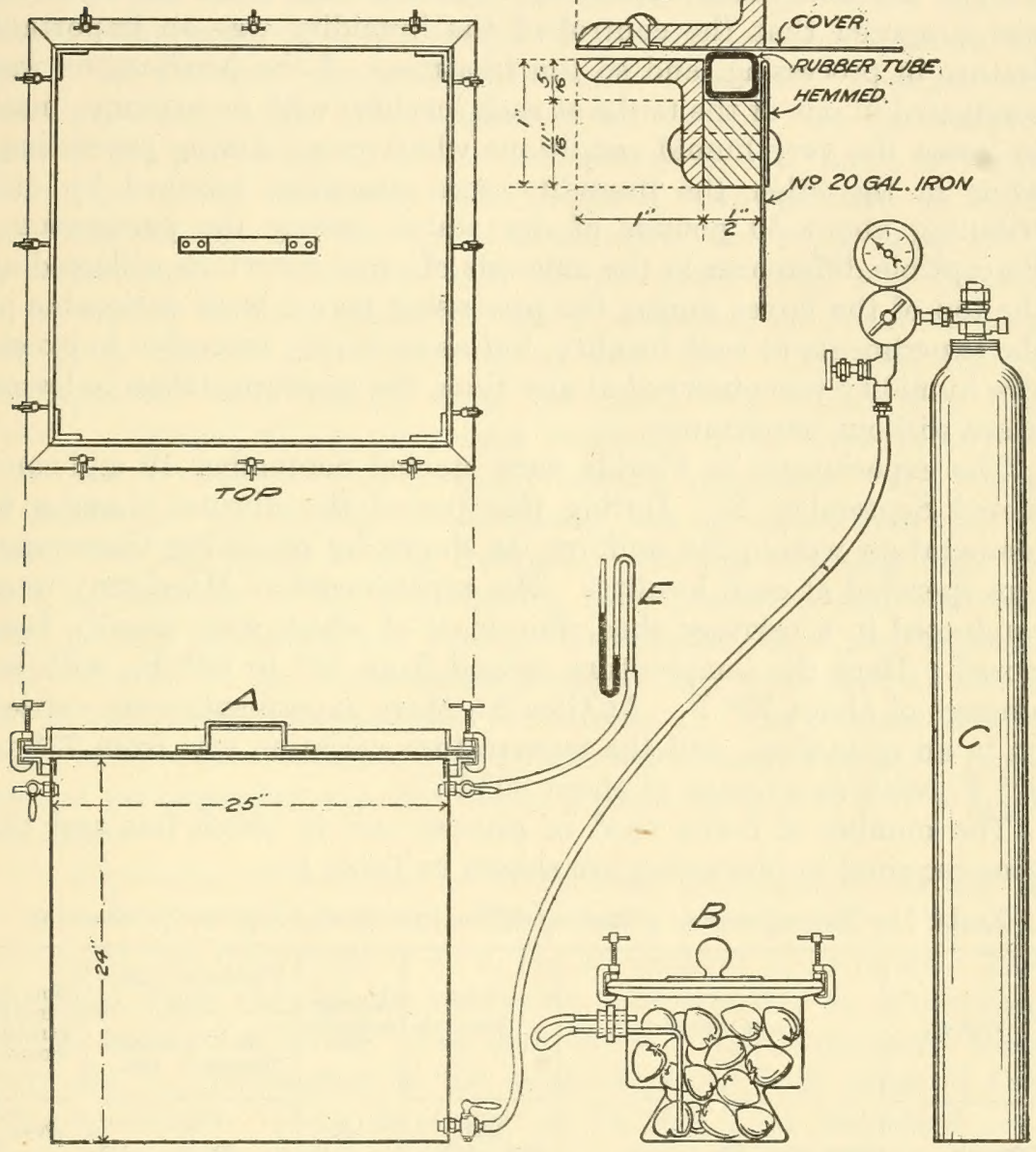

Fig. 1.-Apparatus used in processing Japanese persimmons. A. Tank of galvanized iron. B. Desiceator. C. Cylinder of liquefied carbon dioxid with reducing valve. D. Detail showing construction of edges of the tank and cover. E. Water gauge.

per cubic foot of the gas when expanded to atmospheric pressure. These cylinders of liquefied carbon dioxid are under very high pressure and must not be handled roughly; neither is it safe to allow them to become heated by the direct rays of the sun. The reducing valve, which is shown attached to the cylinder in figure 1, is very useful in regulating the flow of carbon dioxid, and may usually be obtained of 
the dealer supplying the gas. If no reducing valve is used, sudden stoppages will usually occur during the outflow due to the choking of the orifice in the needle valve with solid carbon dioxid. Such stoppage is usually followed by a sudden rush of gas, and very close watching is necessary if annoying accidents are to be avoided.

Processing experiments were conducted at the nurseries of the Griffing Bros. Co. at Macclenny, and at the Glen St. Mary nurseries at Glen St. Mary, using in all cases fruit freshly picked from the trees. Two of the iron tanks were used at each locality. At the outset it was supposed that the control of the humidity was an important feature in processing, and so the treatment of the persimmons was conducted in one of the tanks at each locality, with no attempt made to lessen the very humid conditions which occur during processing, while in the other the humidity was somewhat lessened by distributing about 50 pounds of dry starch among the persimmons. Perceptible differences in the amounts of moisture which collected at the top of the boxes during the processing period were noticeable in the experiments at each locality, but as no injury traceable to excessive humidity was observed at any time, the measures taken to lessen it are without importance.

The experiments in Florida were started September 19 and completed September 27. During this period the diurnal changes in temperature were quite uniform, as shown by recording thermometers operated at each locality. The experiments at Macclenny were conducted in a carriage shed, the doors of which were usually kept closed. Here the temperature ranged from $70^{\circ}$ to $86^{\circ} \mathrm{F}$., with an average of about $77^{\circ} \mathrm{F}$. At Glen St. Mary experinents were carried on in an open shed, and the temperature variation was from $73^{\circ}$ to $99^{\circ} \mathrm{F}$., with an average of about $80^{\circ} \mathrm{F}$.

The number of fruits used in process and in check lots and the time required in processing are shown in Table $I$.

TABLE I.-Time required in processing different varieties of Japanese persimmons.

\begin{tabular}{|c|c|c|c|c|c|c|}
\hline \multirow{2}{*}{ Variety. } & \multirow{2}{*}{ Where processed. } & \multirow{2}{*}{ Date. } & \multirow{2}{*}{$\begin{array}{c}\text { A verage } \\
\text { tempera- } \\
\text { ture. }\end{array}$} & \multicolumn{2}{|c|}{ Number of fruits- } & \multirow{2}{*}{$\begin{array}{l}\text { Time re- } \\
\text { quired in } \\
\text { carbon } \\
\text { dioxid. }\end{array}$} \\
\hline & & & & $\underset{\text { process. }}{\text { In }}$ & $\begin{array}{c}\text { In con- } \\
\text { trol. }\end{array}$ & \\
\hline $\begin{array}{r}\text { Triumph... } \\
\text { Do...... } \\
\text { Imperial.... } \\
\text { Hachiya.... } \\
\text { Do...... } \\
\text { Okame...... } \\
\text { Tane-nashi.. } \\
\text { Do...... } \\
\text { Do...... } \\
\text { Zengi....... } \\
\text { Do...... } \\
\text { Hyakume... } \\
\text { Yemon...... } \\
\text { Costata..... } \\
\text { Taber's } 23 . . .\end{array}$ & 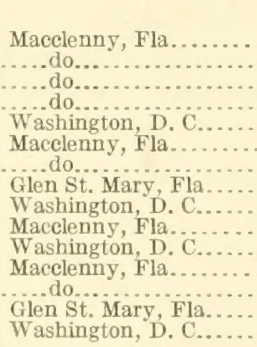 & $\begin{array}{l}1911 . \\
\text { Sept. } 19-22 \ldots \\
\text { Sept. } 22-24 \ldots \\
\text { Sept. } 19-22 \ldots \\
\text { Sept. } 19-26 \ldots \\
\text { Oct. } 5-15 \ldots \ldots \\
\text { Sept. } 19-24 \ldots \\
\text { Sept. } 19-26 \ldots \\
\text { Sept. } 20-27 \ldots \\
\text { Oct. } 7-19 \ldots \ldots \\
\text { Sept. } 25-27 \ldots \\
\text { Oct. } 23-27 \ldots \\
\text { Sept. } 19-22 \ldots \\
\text { Sept. } 20 \ldots-24 \ldots \\
\text { Oct. } 5-7 \ldots \ldots\end{array}$ & \begin{tabular}{r|}
${ }^{\circ} F \cdot$ \\
77 \\
77 \\
77 \\
77 \\
69 \\
77 \\
77 \\
80 \\
69 \\
77 \\
69 \\
77 \\
77 \\
80 \\
69
\end{tabular} & $\begin{array}{r}395 \\
196 \\
219 \\
144 \\
9 \\
49 \\
37 \\
431 \\
474 \\
447 \\
540 \\
3 \\
2 \\
68\end{array}$ & $\begin{array}{r}118 \\
117 \\
100 \\
72 \\
9 \\
25 \\
18 \\
1200 \\
100 \\
253 \\
100 \\
0 \\
0 \\
71\end{array}$ & $\begin{array}{c}\text { Days. } \\
2 \frac{1}{2} \\
13 \\
4 \frac{1}{2} \\
7 \\
10 \\
4 \frac{1}{2} \\
7 \\
7 \\
12 \\
2 \\
4 \\
1 \frac{1}{2} \\
1 \frac{1}{2} \\
4 \\
2\end{array}$ \\
\hline
\end{tabular}

1 Approximately. 
The various lots of persimmons were quite evenly ripened and of the degree of maturity at which they are usually picked for shipment to northern markets, with the exception of Okame (see p. 10).

\section{EXPERIMENTS AT MACCLENNY, FLA.}

At Macclenny the following varieties were processed: Triumph, Imperial, Hachiya, Okame, Tane-nashi, Zengi, Hyakume, and Yemon.

Trinmph.-Two experiments were made with this variety. Two and one-half days and one and two-thirds days in carbon dioxid, respectively, were required before the persimmons were nonastringent. In the first experiment 513 fruits were used, of which 395 were processed, while 118 constituted the control. On the completion of the processing all of the persimmons in the tanks, with the exception of one specimen which softened, were as hard as when placed in process. Of the control 90 were firm, and $2 S$, or 24 per cent, were softening. Three days later the processed fruits were noticed to be rapidly deepening in color, many possessing the beautiful deep red shade characteristic of this variety when ripe. This color change distinguished them sharply from the check lots, which were still yellow. Several of the processed reddened fruits were tasted at this time in contrast with normally ripened specimens. The flavor of the former was slightly but distinetly less agreeable than that of the latter, the fruits lacking freshness. On the following day the firm parsimmons of the experiment, both processed and controls, were packed in carriers and sent to Washington, D. C., by express. They arrived at the department promptly and were kept at about $60^{\circ} \mathrm{F}$. until they were examined on October 2. The processed fruits were found to have softened greatly and were utterly ruined for commercial purposes, but the controls, as a whole, were firm and in good condition.

On September 2.2 a second lot of Triumph persimmons was placed in process at 6 o'clock p. $\mathrm{m}$. These fruits were found to be nonastringent two days later at 10 a. m., an interval of 40 hours. The processed fruits showed the reddening conspicuously on September 26 but had not softened. The firm fruits of the experiment were then sent to Washington in the same shipment with those of the first experiment. L'pon inspection on October 2 the processed persimmons were found to be in very porr condition, resembling closely the first lot of processed Triumph, though they were not so badly softened, whereas the controls were in excellent condition.

From these two experiments it is erident that the variety processes readily in from 40 to 60 hours at Florida temperatures and that after removal from the curbon dioxid it may be kept for four days at these temperatures before deterioration, except a slight loss in $37998^{\circ}-$ Bull. $155-12-2$ 
flator, oceurs. It womill therefore be prarticable to process this variety for local use, since it is no more perishable when remored from the carbon dioxid than are most small fruits or peaches. It is clearly shown, howrorer, that processing greatly injures the naturally excellent carrying qualities of this variety.

Imprial.-This rarety resembles ('ostata in size and shape. $\Lambda$ total period in carbon dioxid of fonr and one-half days was required. Durine kecping for two days after jrocessing 24 per cent softened, while s per cent of the controls softened. The firm processed and (ontrol fruits were sent to Mashington in the same shipment with Triumph. When 'xamined, on October 2, the processed specimens were found to be softening, while the control fruit was in good conbition. As in the case of Triumph, it is clear that while this variety may be procesed for markenting locally it is not advisable to process with a view to shipping long distances.

IIachiger.--This fruit required seven days in which to become nonastringent. On silimment to Washington all of the processed fruits siftened, while the controls remained furm. These softened specimens were delirious in eating quality when examined on October 2, athough they wre not quite so palatable as normally ripened fruits. The differene' was at first noticeable only by careful comparison with softened specimeis among the controls. The processed fruit rapidly lost in eating quality on keeping in the laboratory, the flesh diurkening noticeably from day to day. It is evident that it is impracticable to process this variety except for local use.

Olame.-But relatively few of these fruits were avalable, and they were as a whole very unevenly ripened, the color ranging from green to arange yellow. Care was taken to include in the processed and control lots equal proportions of specimens of the different degrees of ripeness. They processed in four and one-half days. No difference in time of processing the fruits of different degrees of maturity was evident, the immature fruit becoming nonastringent about as rapidly as the more highly rolored persimmons. During the two days' keeping at Florida temperatures following the removal of the processed fruit from the container a larese proportion (35 per cent) of the treated furit softenel, while all of the control remained firm. On shipping to iVashington all of the moesesed fruits had softened by October $\because$, the antrols rematining firm. In this case, therefore, as with the thres variot ies just ment ioned, processing injures the shippiner quality very seriously.

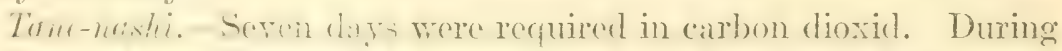

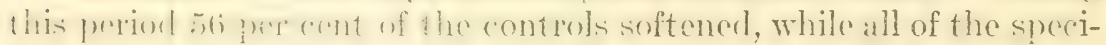
unde in proxes pomainal firm. The examination of the fruits at

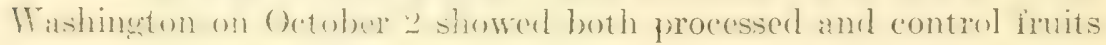
to bo softening. No deterioration in flavor or color such as was 
noted in the case of Trumph and ITachiya occurred with the prosessed fruits of the Tane-nashi variety. When soft the processed specimens could not be distinguished from those that had softened normally.

Zengi.-Two groves of persimmons at the Griffing Bros.' nurseries at Macclenny bear fruit resembling Zengi but differing from it as ordinarily described in that most of the fruit is yellow-fleshed and seedless as well as much larger in size. It closely resembles in habit of tree, lateness, and size and shape the rariety lnown as Taber's 2:3, and indeed the fruits of the two varieties can not be distinguisherd.

A large number of these Zengi persimmons were gathered and placed in process on September 25. Two days later the fruit was found to have become sweet. The processed specimens, together with the controls, were expressed to Washington, D. C., on September 27 and were examined on Octeber'2. In marked contrast to all the other lots experimented with in Florida, the processed fruit as well as the controls endured the shipment without softening. From this time on counts were made of the firm and softened fruits at intervals until Oetober 20, when the fruit had dried out to such an extent that the counts became uncertain. The figures are shown in the following table:

TABLE II.-Rate of softening of processed and unprocessed Zengi persimmons shipped to Washington from Wacclenny and liept at a temperature of about $69^{\circ} \mathrm{F}$.

\begin{tabular}{|c|c|c|c|}
\hline \multirow{2}{*}{ Date. } & \multirow{2}{*}{$\begin{array}{l}\text { Interval after } \\
\text { picking. }\end{array}$} & \multicolumn{2}{|c|}{ I'ercentage of softened fruit. } \\
\hline & & $\begin{array}{l}\text { Processed ( } 447 \\
\text { specimens). }\end{array}$ & $\begin{array}{l}\text { Control (253 } \\
\text { specimens). }\end{array}$ \\
\hline $\begin{array}{r}1911 . \\
\text { Oct. } 7 \ldots \ldots \\
9 \ldots \ldots \\
13 \ldots \ldots \\
16 \ldots \ldots \\
18 \ldots \\
20 \ldots\end{array}$ & $\begin{array}{c}\text { Days. } \\
13 \\
15 \\
19 \\
22 \\
24 \\
26\end{array}$ & $\begin{array}{l}23 \\
39 \\
46 \\
63 \\
69 \\
72\end{array}$ & $\begin{array}{l}30 \\
44 \\
50 \\
55 \\
57 \\
60\end{array}$ \\
\hline
\end{tabular}

It is evident that although processing pereeptibly accelerates softening, the eflect is but slight and not apparent until 22. days after pieking. The natural excellent shipping qualities of the variety were therefore minjured. No deterioration in fla vor or color oceurnd. The processed persimmens were excellent in flavor at all times befire and after softening.

Hyglenme and Yemon. - But three and two specimens, respectively, of these rarieties were available for study. They were processed in desichators, becoming nonastringent in 36 hours. It is regretted that it was not possible to secure more specimens so as to determine the effect of processing on the rate of softening. Both varieties are of distinct promise in view of the fan that they liecome nomatringent very readily. 


\section{EXPERIMENTS AT GLEN ST. MARY, FLA.}

It Glen St. Mary the processing tanks were filled on September 20 with Costat and Tane-nashi. Costat a required four days, while Tanemathi processed slowly, requiring seven days before the fruit became redible. During this time at least one-third of the control Tane-nashi liad softened. For sereral reasons an exact count of the controls was not made. The processed Costata and Tane-nashi were sent to Washington, D. C., by express on September 27, together with the firm specimens of their controls. The fruit was kept at about $60^{\circ} \mathrm{F}$. after its arriral in Warlington until October 3 , when it was examined.

Costata.-The processed fruits had softened much more than the controls and had darkened somewhat, so that they were hardly marketable. The controls shipped successfully.

Tane-nashi.--The processed fruit was found to be in good condition on examination in Washington and the unprocessed fruit also stood the transportation excellently. In the following table are shown the percentages of softened fruits when first examined, and two and four days later.

TABLE III. - Rate of suftening of processed Teni-nashi persimmons shipped to Wastington after processing at Glen St. Mary and kept at a temperature of about $69^{\circ} \mathrm{F}$.

\begin{tabular}{|c|c|c|c|}
\hline \multirow{2}{*}{ Date. } & \multirow{2}{*}{$\begin{array}{l}\text { Interval after } \\
\text { picking. }\end{array}$} & \multicolumn{2}{|c|}{ Percentage of softened fruit. } \\
\hline & & $\begin{array}{l}\text { Processed (431 } \\
\text { specimens). }\end{array}$ & $\begin{array}{l}\text { Control (125 } \\
\text { specimens). }\end{array}$ \\
\hline $\begin{array}{r}1911 . \\
\text { Oct. } 3 \ldots . . \\
5 \ldots . \\
7 \ldots\end{array}$ & $\begin{array}{c}\text { Days. } \\
13 \\
15 \\
17\end{array}$ & $\begin{array}{l}38 \\
81 \\
99\end{array}$ & $\begin{array}{l}33 \\
57 \\
77\end{array}$ \\
\hline
\end{tabular}

In this instance ir will be noted that the processed fruit is not compared with the original control, but with the fruits of the control which were firm on sontember 27 . A distinct eflect of the processing in halstening the rute of softening of the persimmons is evident.

\section{EXPERIMENTS AT WASHINGTON, D. C.}

Fon varieties were processed at Washington. These were Hachiya and Taber's 2:3, from Mr. Macklin at Dinsmore, Fla.; Zengi, from the frifling Bros. (o). at Macelemm; and 'Tane-nashi, from the Glen St. Mary Nurseries Co.

Hachigh.-Eighteen large, evenly ripened fruits were received on ()etober 5. Nine were placed in carbon dioxid in desiccators, while the remainder erved as checks. Ten days were required for processing at an averuge !aboratory temperature of about $69^{\circ} \mathrm{F}$. Six days later all of the froressed fruits were softening, while three of the controls still remined firm. The processed fruits gradually darkened 
and lost flavor. This result confirms the experience with Hachiya processed in Florida.

Taber's 23.-This variety, which so greatly resembles the Zengi grown at Macclenny (see p. 11), was received on October 5. The fruits placed in carbon dioxid became nonastringent at laboratory temperatures averaging $69^{\circ} \mathrm{F}$. in two days. All of the 68 fruits so processed remained firm, while of 71 control specimens 8 , or 11 per cent, were softening at the end of the two days. The data on the subsequent rate of softening are given in the following table:

TABLE IV.-Rate of softening of processed and unprocessed Taber's 23 persimmons.

\begin{tabular}{|c|c|c|c|}
\hline \multirow{2}{*}{ Date. } & \multirow{2}{*}{$\begin{array}{l}\text { Interval after } \\
\text { placing in } \\
\text { carbon dioxid. }\end{array}$} & \multicolumn{2}{|c|}{ Percentage of softened fruit. } \\
\hline & & $\begin{array}{l}\text { Processed (68 } \\
\text { specimens). }\end{array}$ & $\begin{array}{l}\text { Control (71 } \\
\text { specimens) }\end{array}$ \\
\hline $\begin{array}{r}1911 . \\
\text { Oct. } 7 \ldots . . \\
14 \ldots \\
17 \ldots \\
25 \ldots \\
30 \ldots \\
\end{array}$ & $\begin{array}{c}\text { Days. } \\
2 \\
9 \\
12 \\
20 \\
25\end{array}$ & $\begin{array}{r}0 \\
25 \\
25 \\
45 \\
63\end{array}$ & $\begin{array}{l}11 \\
18 \\
34 \\
48 \\
63\end{array}$ \\
\hline
\end{tabular}

The rate of softening is thus shown to be practically unaffected by the processing. No darkening of the flesh or deterioration in flavor occurred at any time, either before or after softening.

Tane-nashi.-A large shipment of Tane-nashi was received by express on October 7 and placed at once under observation. One carrier of fruit was held in the laboratory at a temperature averaging $69^{\circ} \mathrm{F}$, another was kept in a refrigerator at about $52^{\circ} \mathrm{F}$, and a third was held in cold storage at $35^{\circ} \mathrm{F}$. These arerage temperatures are estimated from the record sheets of thermometers kept beside the respective samples. These lots were used as controls of fruit which was processed at room temperature and then stored at these three temperatures. Four hundred and seventy-four persimmons were placed in process. These became nonastringent after an interval of 12 days, and all remained firm except 17 , or 4 per cent, which were softening from decay. During the same interval, of the controls at room temperature, 82 per cent became soft, and of the fruits held at refrigerator and cold-storage temperatures, 42 per cent and 6 per cent, respectively, softened. Three lots of 100 specimens each of the firm processed persimmons were selected for keeping at the three temperatures mentioned. All of the fruits were wrapped. The rates of softening of each of these three lots and their controls were determined by counting at intervals. The results are shown in Table $\mathrm{T}$ and are given graphically in figure 2 . 
TABLE V.-Tate of softening of proerssed and unprocessed Tanc-nashi persimmons kept at thrce different tempcratures.

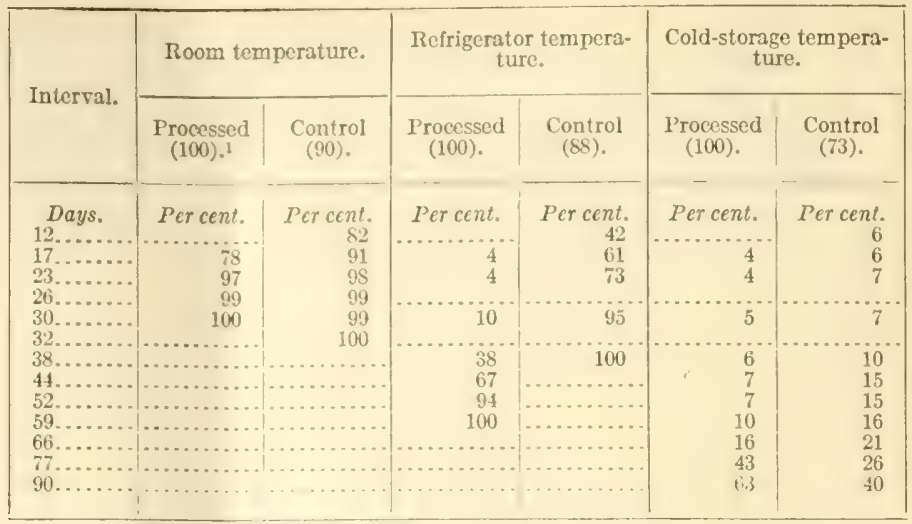

${ }^{1}$ The total number of fruits used in each lot is given at the top of each column.

The persimmons softencel after removing from the process decidedly more rapidly at room temperature than did the controls. The refriserator temperature delayed the softening of the processed fruit markedly, but as som is rapid soltening began the rate was about the same as that of the control; the curres are practically parallel. In cold storage the processed fruit at first softened less and then more rapidly than the control. In no case was conspicuous injury to the fruit caused by the kerping in carbon dioxid. It must be kent in mind, howerer, that the data are incomplete, as studies on the behavior of the fruit on withdrawal from cool temperatures are lacking. Certain abnormalities, such als darkening of the flesh at bruised places and blackening of the flesh near the calyx, occurred after 29 days in refrigerator storage, and it is probahle that the persimmons would not have held up well if withdrawn at this time and kept under market conditions. The abmommalities were more frequent among the processed fruits than among the controls. The results of this experiment show that procensing is fairly successful with this variety. 'The fact that a lonere time was recpuired for the persimmons to become nonastringent in Washington than in Florida is probably due to differences in temperature.

Zengi.-A large number of the yellow-fleshed Zengi were received late in the aftermom of (october 23 , and were placed in process on the following morning. About 1,100 fruits were received, and of these Sto perfectly sombl and firm specimens were selected for the experiments in processing. They were divided into several lots, the plan of the experiment being identical with that just described for Tane-nashi. Three lots of 100 fruits salch were placed in common, refrigerator, and cold storage, respectively, and the remainder placed in process at room temperatures. The average temperatures were practically the same as 


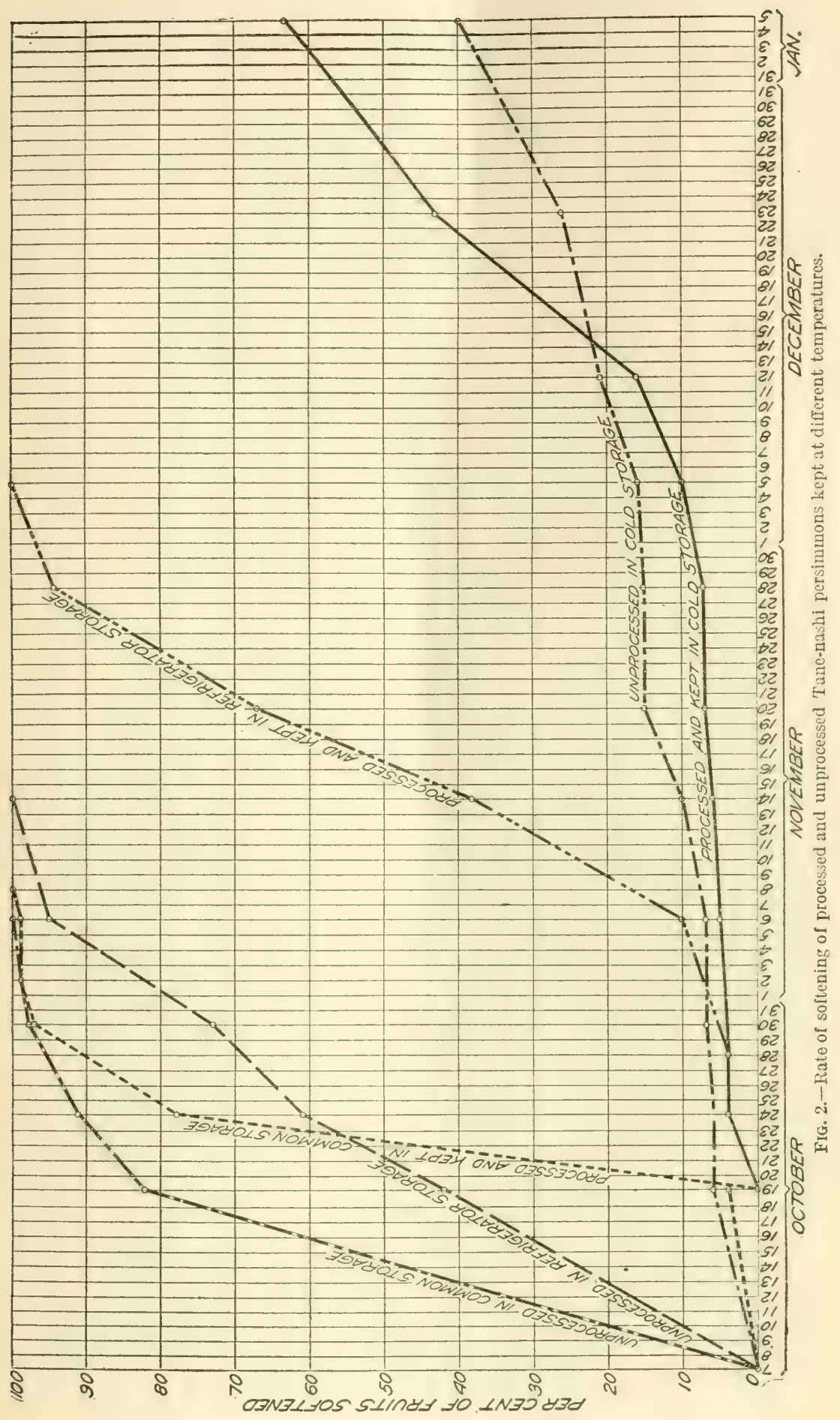


in the preceding experiment with Tane-nashi. Four days were required in processing. All fruits but one remained firm, while of the controls at room temperature 16 per cent had softened. Three lots of 100 specimens each of the processed fruits were kept at the three temperatures and counts of all lots were made at intervals, all fruits being kept wrapped. The rate of softening of the various lots of persimmons is shown in Table VI and graphically in figure 3.

TABLE VI.-Rate of softening after processing of Zengi persimmons liept at three different temperatures.

\begin{tabular}{|c|c|c|c|c|c|c|}
\hline \multirow{2}{*}{ Interval. } & \multicolumn{2}{|c|}{ Room temperature. } & \multicolumn{2}{|c|}{$\begin{array}{l}\text { ReIrigerator tempera- } \\
\text { ture. }\end{array}$} & \multicolumn{2}{|c|}{$\begin{array}{c}\text { Cold-storage tempera- } \\
\text { ture. }\end{array}$} \\
\hline & Processed. & Control. & Processed. & Control. & Processed. & Control. \\
\hline Days. & Per cent. & Per cent. & Percent. & Per cent. & Per cent. & Pcrcent. \\
\hline ii.. & 2 & $\begin{array}{l}10 \\
29\end{array}$ & 0 & i & 0 & 1 \\
\hline$\frac{9}{3}$ & 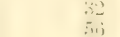 & $\therefore$ & 2 & 2 & 0 & 1 \\
\hline 15. & $\because 1$ & i) & & & & \\
\hline 14. & it & $\because 9$ & 6 & & & \\
\hline 27 & 1,5 & 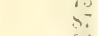 & 17 & $\begin{array}{l}1 \pm \\
33\end{array}$ & $\begin{array}{l}0 \\
0\end{array}$ & 2 \\
\hline 3. & & $\therefore$ & 91 & ift & 0 & 2 \\
\hline 42 & & & 100 & $1(9)$ & 0 & 3 \\
\hline 49. & & & & & 2 & 7 \\
\hline & & & & & 17 & $\begin{array}{l}19 \\
36\end{array}$ \\
\hline & & & & & 36 & 71 \\
\hline
\end{tabular}

In many respects the curves resemble those obtained with Tanenashi. The processing period, however, is very much shorter. The rate of softening of this rariety was even better controlled by cooling to refrigerator temperature than in the case of Tane-nashi. The processed persimmons softened slightly more rapidly than the controls at room and refrigerator temperatures, respectively, but the difierences are too small to be of practical importance. The processed fruit in cold storage softened somewhat less rapidly than the controls. No abnormalities among the firm or softened Zengi persimmons occurred on keeping either at room, refrigerator, or cold storage temperatures.

Lots of from 6 to 12 specimens of the processed Zengi fruit were mailed on October 27 to 12 retail fruit dealers in various cities and to 5 growers of persimmons in the South. Of the fruit dealers, 8 expressed the opinion that a demand would have to be created for processed fruit before it could be expected to sell. Only 3 commented on the excellent quality of the persimmons, while 2 expressed at preference for the normally softened fruit. On the whole, the comments of the fruit dealers were less farorable than was expected. This probably indicates that less difliculty is now being had in selling the astringent Japanese persimmons in their natural state than was the case a few 


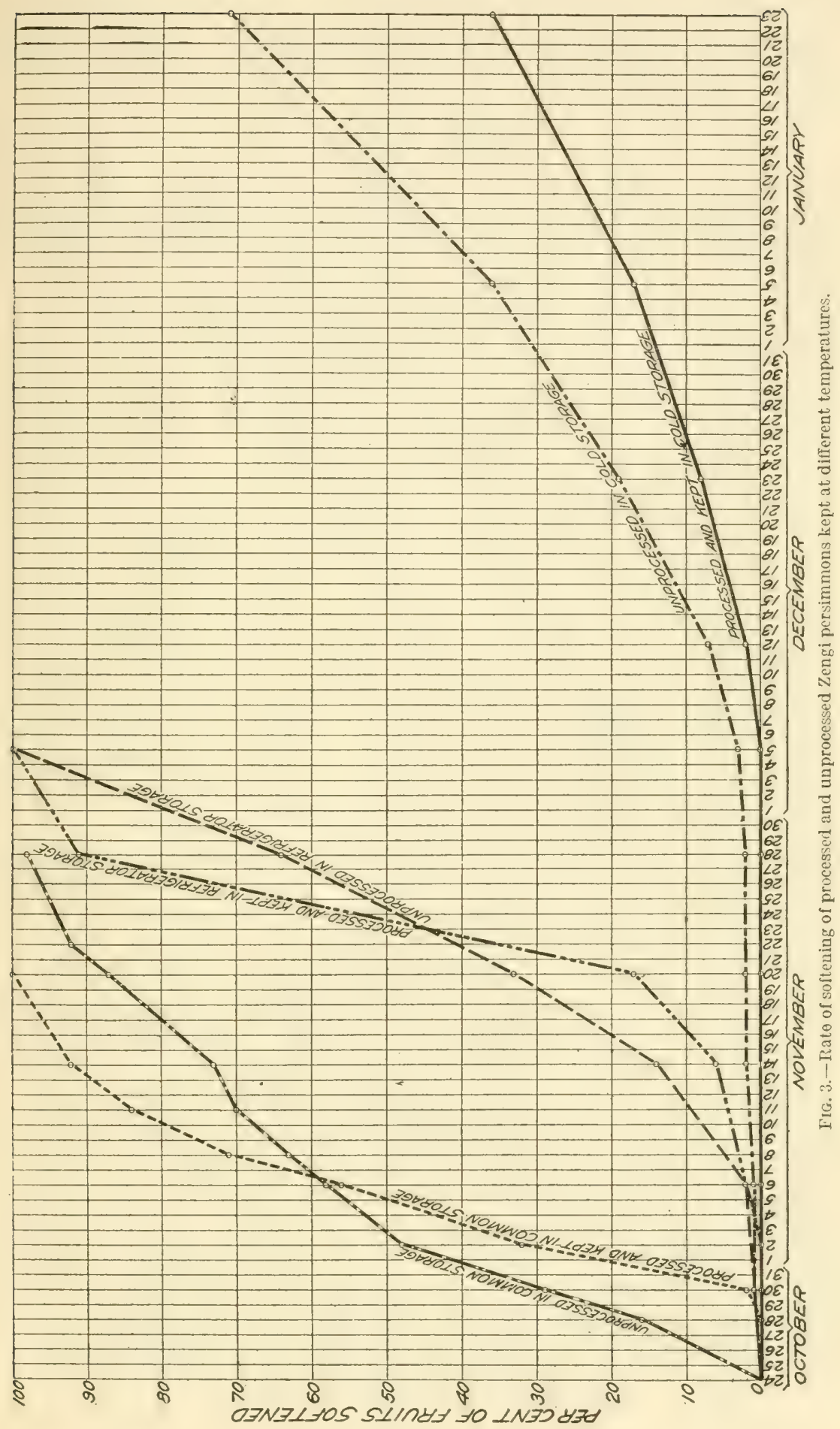


years ago. That the astringency of the Japanese persimmon will continue to retard greatly its wide introduction seems, however, probable. All of the 5 growers pronounced the samples of most excellent eating quality.

\section{DISCUSSION OF RESULTS.}

From the experiments just described some idea is given of the value of persimmon processing when applied to the varieties of Japanese persimmons commonly grown in this country. It can be recommended generally for treating the fruit for local distribution, as none of the varieties when processed were more perishable than are the small fruits or peaches. It can not be recommended, however, if the fruit is to be subsequently shipped for long distances except in the case of the seedless yellow-fleshed Zengi and Taber's 23, as the naturally fine shipping qualities of the persimmons are greatly injured. Zengi and Taber's 23 are not unfavorably affected. Possibly the fruit could be successfully shipped for long distances after precooling, as cool temperatures retard the rate of softening considerably, but this is a subject for further study. Processing may be successfully employed after shipment, and it would seem to be particularly useful in so treating those varieties which, when ripened naturally, must become extremely soft before they are edible. The most conspicuous example of persimmons of this type is Hachiya, the most beautiful as well as one of the largest of all varieties. If placed in carbon dioxid when it is highly colored but firm it may be rendered nonastringent in a much shorter time than when the fruit is more immature, and when so processed is of most delicious eating quality.

It is hoped that the ease by which the remarkable change in the fruit may be brought about will induce others to experiment with it, as it is probable that it must be repeatedly tried by a number before its place in the persimmon industry is definitely established.

Col. Watrous ${ }^{1}$ in his report on persimmon processing by the Japanese method notes that it is expert work requiring skill and judgment; this is true also of processing in carbon dioxid. The maturity of the fruit and the temperature must be considered by the operator, while the time required in processing, the acceleration in rate of softening, and effect on flavor must be determined before it is possible properly to draw conclusions as to the application of the process to any particular variety. The operator is especially cautioned not to use apparatus of a makeshift nature; for example, the employment of wooden containers for the fruit, which though apparently air-tight may allow diffusion of gases through the wood. The air must be displaced and kept away from the main lot of fruit in process for the time indicated by the small lots in the desiccators. If the air is not 
so excluded delays in processing may be expected, while the fruit may soften rapidly both in process and afterwards and misleading results be obtained.

A number of important varieties remain to be tested to determine how rapidly they become nonastringent when placed in carbon dioxid and the effect of the treatment on the rate of softening and on the flavor. Among these are Yemon, Hyakume, Taber's 129, and the newly introduced Chinese and Japanese varieties which are not yet fruiting in sufficient quantity for such experiments.

\section{PREPARATION OF DRIED PERSIMIMNS.}

From time to time during the past few years persimmons have been dried in a steam-heated evaporator at the Bureau of Chemistry. Until the present season such experiments were purely of a preliminary nature. It was developed, however, that certain precautions must be taken to insure satisfactory results. It was found necessary to peel before drying, as otherwise the skin becomes very tough and the shape of the fruit is distorted. It was desirable to peel and slice in such a way that the fruit is not stained by contact with iron knife blades, which quickly become coated with the blue-black iron-tannin salts. Nickel-plated knives were found useful. To secure the best appearance of the dried fruit it should be sliced at right angles to the axis, and spread on trays of galvanized or tinned wire netting in such a way that every part of each slice is well aerated, as darkening occurs wherever the aeration is not sufficient. It was found best to dry at temperatures not exceeding $122^{\circ} \mathrm{F}$. The variety Tane-nashi is most suitable for drying. It is of large size and the trees are productive. As there are no seeds circular disks showing the beautiful star-shaped centers can be cut easily and the fruit dries practically without change in color.

A large quantity of Tane-nashi grown at Glen St. Mary, Fla., was dried at Washington, D. C., during the season of 1911, using the precautions just mentioned. It became nonastringent soon after placing in the drier. When removed, the dried slices were kept in a closed container for several days so that they became equalized in moisture content and were pliable. They were then pressed into small bricks and distributed to a number of persons interested in persimmons. The comment on the whole was very favorable. Many likened them to dried figs or dates. Samples have been kept under observation in the laboratory in tin boxes held in closed glass jars for three months. The color darkened slightly during this interval, but the fruit remained perfectly sound and the flavor excellent. The drying of the seedless variety Tane-nashi is of much promise in view of the ease with which a very attractive product may be prepared. 


\section{SUMMARY.}

A method of processing persimmons on a large scale by keeping in carbon dioxid is described and an account is given of experiments in the application of the method to persimmons in Florida and at Washington, D. C.

(1) All of the varieties tried became nonastringent when kept in carbon dioxid. The intervals in days necessary for processing at Florida temperatures are given in parentheses following the name of

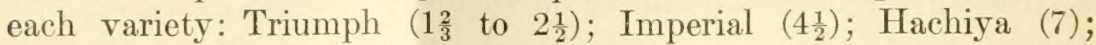

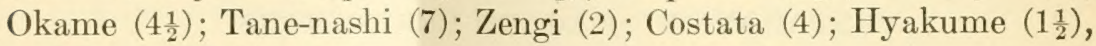
and Yemon $\left(1 \frac{1}{2}\right)$.

(2) All of these varieties were processed on a large scale in Florida and subjected to a shipping test with the exception of Hyakume and Yemon. With one exception (yellow-fleshed Zengi) processing greatly injured the naturally excellent shipping qualities of the fruit. Tane-nashi was less seriously affected than many of the others. Zengi was practically unaffected in shipping quality by the treatment. Processing, therefore, can not be recommended for persimmons which are to be shipped long distances with the exception of Zengi and Taber's 23 (with which the yellow-fleshed Zengi is possibly identical), but it is practicable to process all of the varieties mentioned for marketing locally.

(3) No undesirable effects were produced by high humidity while in process.

(4) Processing in carbon dioxid at Washington required more time than in Florida, probably on account of the lower temperatures.

(5) Keeping at refrigerator or cold storage temperatures considerably retarded the softening of the persimmons.

(6) An excellent product in appearance and flavor was obtained by drying Tane-nashi persimmons.

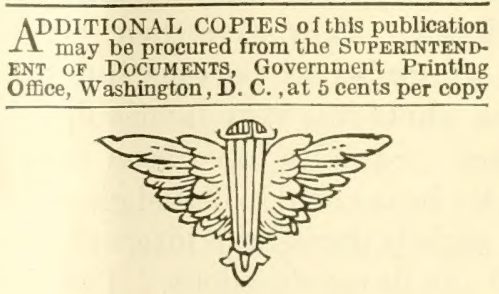



00009298629 